\title{
ASPOROGENOUS MUTANTS OF BACILLUS SUBTILIS
}

\author{
SUMIO OKAMURA, KAZUO IZAKI AND HAJIME TAKAHASHI \\ Department of Agricultural Chemistry, Faculty of Agriculture, \\ Tohoku University, Sendai 980
}

(Received April 22, 1970)

\begin{abstract}
Several asporogenous mutants of Bacillus subtilis, which seemed to be one of early sporulating mutants, were obtained by ultraviolet irradiation (strain No. 71 and 7) or acriflavine treatment (strain No. 61). These mutants grew normally in Spizizen's minimal medium and were able to produce amylase, protease, and antibiotics as the wild type in their sporulating stages. Compared with sporulating stage cells of the wild strain, protein degradation during sporulation was of the same degree but protein synthesis did not occur at their sporulating stage in these asporogenous mutants. Therefore, these mutants could not synthesize $\mathrm{NADH}_{2}$ oxidase, glucose dehydrogenase, and dipicolinate which characteristically appear during sporulation. However, ${ }^{3} \mathrm{H}$-uracil incorporation experiment during sporulation stage indicated that RNA synthesis occurred at their sporulating stage in these asporogenous mutants.
\end{abstract}

A number of asporogenous mutants were isolated by many workers to study the mechanism of bacterial sporulation. SCHAEFFER et al. showed that the ability to form spores can be restored by transformation in asporogenous mutants of $B$. subtilis (1). SCHAEFFER and IONESCO analyzed several asporogenous mutants and recognized several unlinked genes which control sporulation (2). SPIZIZEN (3) reported that a group of spore genes were clustered with genes for proteolytic enzymes, an antibacterial factor, and a competence factor, by transformation experiment. TAKAHASHI (4-6) obtained many asporogenous mutants of $B$. subtilis and demonstrated, using the transduction experiments, that spore markers of $B$. subtilis are distributed randomly among the chromosomes. Recently, SPIZIZEN (7) also demonstrated by transformation techniques that the defective sites of mutants are scattered and are present in all four linkage groups. With the progress on genetic analysis of sporulation by the use of asporogenous mutants, it is desirable to investigate the defects of these asporogenous mutants by biochemical methods to understand the mechanism of sporulation. We have obtained several asporogenous mutants of $B$. subtilis and investigated the biochemical characteristics of these mutants. 


\section{MATERIALS AND METHODS}

Bacterial strains. Bacillus subtilis MARBURG $111\left(\mathrm{leu}^{-}\right)$strain used throughout this experiment was kindly supplied by Dr. H. Saito, The Institute of Applied Microbiology, University of Tokyo, and was used as sporogenous $\left(\mathrm{sp}^{+}\right)$strain throughout the experiments. Staphylococcus aureus (B-71-1) employed as the test organism for antibiotic production was from The Institute of Applied Microbiology, University of Tokyo.

Chemicals. Acriflavine was purchased from the Tokyo Kasei Kogyo Co., Ltd. (Tokyo). ${ }^{3} \mathrm{H}-\mathrm{L}-L e u c i n e(200 \mathrm{mCi} / \mathrm{mM}),{ }^{3} \mathrm{H}-\mathrm{DL}-$ phenylalanine $(1590 \mathrm{mCi}$ $/ \mathrm{mM})$, and ${ }^{3} \mathrm{H}$-uracil $(5000 \mathrm{mCi} / \mathrm{mM})$ were purchased from the Daiichi Chemical Co., Ltd. (Tokyo). Actinomycin was kindly supplied by Prof. H. Yonehara, The Institute of Applied Microbiology, University of Tokyo.

Media. The following growth and sporulation media were used. LLeucine $(10 \mu \mathrm{g} / \mathrm{ml})$ supplemented in Spizizen's minimal medium $(8)$ containing per liter of deionized water, glucose $5.0 \mathrm{~g}, \mathrm{KH}_{2} \mathrm{PO}_{4} 6.0 \mathrm{~g}, \mathrm{~K}_{2} \mathrm{HPO}_{4} 14.0 \mathrm{~g}$, sodium citrate $\cdot 2 \mathrm{H}_{2} \mathrm{O} 1.0 \mathrm{~g},\left(\mathrm{NH}_{4}\right)_{2} \mathrm{SO}_{4} 2.0 \mathrm{~g}$, and $\mathrm{MgSO}_{4} \cdot 7 \mathrm{H}_{2} \mathrm{O} 0.2 \mathrm{~g}$, pH 7.0 , was used. Glucose was sterilized by autoclaving separately. In some cases, $0.5 \%$ glycerol sterilized separately was used instead of glucose.

Modified SCHAEFFER's medium (9) containing polypepton $5.0 \mathrm{~g}$, meat extract $3.0 \mathrm{~g}, \mathrm{MgSO}_{4} \cdot 7 \mathrm{H}_{2} \mathrm{O} 0.25 \mathrm{~g}, \mathrm{KCl} 1.0 \mathrm{~g}$, and $\mathrm{FeCl}_{3} \cdot 6 \mathrm{H}_{2} \mathrm{O} \quad 10^{-3} \mathrm{mmoles}$ was also used and $\mathrm{pH}$ was adjusted to 6.7. $\mathrm{CaCl}_{2} \cdot 2 \mathrm{H}_{2} \mathrm{O} 1.0$ mmoles and $\mathrm{MnCl}_{2} \cdot 4 \mathrm{H}_{2} \mathrm{O}$ $10^{-2}$ mmoles were added separately to the above medium after autoclaving.

Isolation of asporogenous mutants by ultraviolet irradiation. Cells of $B$.

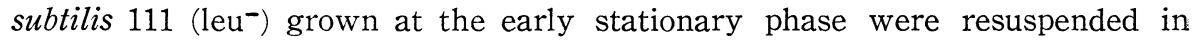
the fresh Schaeffer medium, and were irradiated by a 10-W Mitsubishi Electric germicidal ultraviolet lamp at a distance of $42 \mathrm{~cm}$ from the surface of the liquid for $170 \mathrm{sec}$, and $99.9 \%$ killing was effected. After irradiation, the cells were cultured again in the Schaeffer medium at $30^{\circ}$ for $12 \mathrm{hr}$ and were then plated on solid Schaeffer medium. $\mathrm{Sp}^{+}$colonies were usually opaque and dark brown while $\mathrm{sp}^{-}$colonies could be detected easily by their translucent appearance after growing for 4-5 days at $40^{\circ}$ (1).

Isolation of asporogenous mutants by acriflavine treatment. Experiments were carried out as described by SLEPECKY (10) with a slight modification. B. subtilis $111\left(\mathrm{leu}^{-}\right)$was precultured in Spizizen's minimal medium supplemented with $0.002 \%$ polypepton for $18 \mathrm{hr}$ at $30^{\circ}$. These cells were then inoculated into the same minimal medium. The inoculum size was approximately $10^{6}$ viable cells per $\mathrm{ml}$ and they were grown with shaking at $45^{\circ}$. Acriflavine was dissolved in deionized water and autoclaved. Acriflavine in a final concentration of $0.6 \mu \mathrm{g} / \mathrm{ml}$ was added to these cell suspensions at $0.5 \mathrm{hr}$ after the initiation of growth. Cells were grown with shaking for 24 $\mathrm{hr}$ at $45^{\circ}$. Samples were then diluted and spread on the Schaeffer medium to isolate asporogenous mutants.

Sporulation frequency. To determine the frequency of sporulation, test 
strains were grown in Schaeffer's sporulation broth in shaking flasks for 65 $\mathrm{hr}$ at $30^{\circ}$. The suspension was diluted appropriately and plated on the Schaeffer agar medium to examine total viability of the population. A second sample was heated at $80^{\circ}$ for $30 \mathrm{~min}$, then diluted, and plated on a similar medium to examine spore counts.

Dipicolinate assays. The test strains were grown in the Schaeffer medium for $72 \mathrm{hr}$ at $30^{\circ}$. Then the culture was centrifuged at $5,500 \times g$ for $5 \mathrm{~min}$ and separated into cells and supernatant fraction. Dipicolinate content in both fractions was measured by the method of JANSSEN et al. (11).

Disruption of cells. The wild strain (No. 111) and asporogenous mutants (No. 61, 71, and 7) were grown in the Schaeffer medium. The cells were harvested from $750 \mathrm{ml}$ of culture liquid by centrifugation at $5,500 \times g$ for 5 min, washed, and resuspended in $15 \mathrm{ml}$ of $0.01 \mathrm{M}$ phosphate buffer ( $\mathrm{pH} 7.4$ ), giving approximately $70 \mathrm{mg} / \mathrm{ml}$ (dry weight) cell concentration. The cells were disrupted by a Kubota sonic oscillator at $10 \mathrm{kc}$ for $20 \mathrm{~min}$. The insoluble debris was removed by centrifugation at $15,000 \times g$ for $30 \mathrm{~min}$. The supernatant fraction thus obtained was used as an enzyme preparation. In some cases, this supernatant fraction was centrifuged at $105,000 \times g$ for $3 \mathrm{hr}$ and a particulate fraction was obtained. This particulate fraction was resuspended in $5 \mathrm{ml}$ of $0.01 \mathrm{M}$ phosphate buffer ( $\mathrm{pH} 7.4$ ) and also used as an enzyme preparation. All operations were carried out at $0^{\circ}$.

Protein was estimated according to the procedure of LOWRY et al. (12).

Enzyme assays. $\quad \mathrm{NADH}_{2}$ oxidase was assayed at $30^{\circ}$ according to SzULMAJSTER and SCHAEFFER (13). The cuvette contained $0.36 \mu$ moles of $\mathrm{NADH}_{2}$, $300 \mu$ moles of phosphate ( $\mathrm{pH} 7.4)$ and $0.1 \mathrm{ml}$ of enzyme, in a total volume of $3.0 \mathrm{ml}$. The decrease in optical density (OD) at $340 \mathrm{~m} \mu$ was recorded using a Hitachi spectrophotometer (Model EPS-3). Specific activity was expressed as $\mu$ moles $\mathrm{NADH}_{2}$ oxidized/mg protein $/ \mathrm{min}$.

Glucose dehydrogenase was assayed at $30^{\circ}$ by a modification of the method of SADOFF et al. (15). The cuvette contained $6.0 \mu$ moles of NAD, $0.36 \mu$ moles of $\mathrm{NADH}_{2}, 175 \mu$ moles of phosphate ( $\mathrm{pH} 7.4$ ), $300 \mu$ moles of glucose, and $0.1 \mathrm{ml}$ of enzyme in a total volume of $3.0 \mathrm{ml}$. All the reagents except glucose were mixed first and the reaction was allowed to proceed for $5 \mathrm{~min}$ to determine the rate of $\mathrm{NADH}_{2}$ oxidation by $\mathrm{NADH}_{2}$ oxidase under these conditions, then glucose was added so that the increase in OD $(340 \mathrm{~m} \mu)$ was detected for $\mathrm{NADH}_{2}$ production by glucose dehydrogenase. Specific activity was expressed as $\mu$ moles NAD reduced/mg protein $/ \mathrm{min}$.

Qualitative estimation of various exo-enzymes and antibiotics

Protease production. Test strains were grown on the Schaeffer agar medium, supplemented with $1 \%$ casein, for $48 \mathrm{hr}$ at $30^{\circ}$. Then a small volume of $25 \%$ trichloroacetic acid was overlayered on these plates. After several minutes, the plates became turbid and protease-forming organisms produced clear zones around the colonies, whereas non-protease-forming mutants did not show such a clear zone. 
Amylase production. Test strains were grown on the Schaeffer agar medium supplemented with $1 \%$ starch for $48 \mathrm{hr}$ at $30^{\circ}$. Then a small volume of iodine solution was overlayered on these plates. After several minutes, the plates became violet and amylase-forming organisms produced clear zones around the colonies, whereas non-amylase-forming mutants produced no such clear zone.

Antibiotic production. Test strains were grown in the Schaeffer medium with shaking for $30 \mathrm{hr}$ at $30^{\circ}$. The cultures were centrifuged at $5,500 \times g$ for $5 \mathrm{~min}$ and the supernatant fractions were obtained. A pulp disc was soaked in the supernatant from each culture and then placed on the Schaeffer agar medium containing a suspension of $10^{7}$ cells per $\mathrm{ml}$ of Staphylococcus aureus. After $48-\mathrm{hr}$ incubation at $30^{\circ}$, the plates were examined. The antibiotic activity was detected by a large halo around the pulp disc.

Measurement of protein breakdown. Each of test strains was grown in $100 \mathrm{ml}$ of the Schaeffer medium containing $100 \mu \mathrm{Ci}$ of ${ }^{3} \mathrm{H}$-L-leucine. After 13.5 $\mathrm{hr}$, when sporulation was induced under these conditions, 1.0 mmoles of unlabeled L-leucine was added to the culture. Cell suspension $(0.1 \mathrm{ml})$ was sampled at appropriate time intervals, and then $0.1 \mathrm{ml}$ of cold $10 \%$ trichloroacetic acid (TCA) was added to this suspension to precipitate proteins. After $1 \mathrm{hr}$ at $0^{\circ}$, the precipitate formed was placed on glass fiber by filtration and washed twice with cold 5\% TCA, once with ethanol-ether $(3: 2)$, and finally once with ether. The dried glass fiber was placed in $10 \mathrm{ml}$ of scintillation solution and radioactivity of the acid-precipitable ${ }^{3} \mathrm{H}$-leucine was counted in a liquid scintillation spectrometer. Counting efficiency was approximately $8 \%$.

Glass fiber filters (GB-60) were purchased from the Tōyō Roshi Co., Inc. Scintillation fluid consisted of $4.0 \mathrm{~g}$ of 2,5-diphenyloxazole (PPO) and $0.1 \mathrm{~g}$ of 1,4-bis [2-(4-methyl-5-phenyloxazolyl)] benzene (dimethyl-POPOP) dissolved in 1 liter of toluene.

Protein synthesis during sporulation. Each strain was grown in $100 \mathrm{ml}$ of the Schaeffer medium. After $13.5 \mathrm{hr}, 50 \mu \mathrm{Ci}$ of ${ }^{3} \mathrm{H}$-DL-phenylalanine was added to the culture. Cell suspension $(0.1 \mathrm{ml})$ was sampled at appropriate time intervals, and radioactivity of the acid-precipitable fraction was counted as described above.

$R N A$ synthesis during sporulation. Each strain was grown in $100 \mathrm{ml}$ of the Schaeffer medium. After $16 \mathrm{hr}$, when protein synthesis for sporulation occurred in wild strain, $50 \mu \mathrm{Ci}$ of ${ }^{3} \mathrm{H}$-uracil was added to the culture. Cell suspension $(0.1 \mathrm{ml})$ was sampled at appropriate time intervals, and radioactivity of the acid-precipitable fraction was counted as described above.

$R N A$ content. To measure the RNA content in the cells, $1 \mathrm{ml}$ of cell suspension was sampled periodically. RNA in the cells was extracted by the method of SCHNEIDER (16) and RNA content was measured by the orcinol reaction (17). 
Table 1. Frequency of sporulation in wild and asporogenous mutants.

The test strains were grown in Schaeffer sporulation broth for $65 \mathrm{hr}$ at $30^{\circ}$.

\begin{tabular}{c|c|c}
\hline Mutant & $\begin{array}{c}\text { Viable count } \\
\text { cells } \mathrm{ml})\end{array}$ & $\begin{array}{c}\text { Spore count } \\
\text { (cells } / \mathrm{ml})\end{array}$ \\
\hline $111^{a}$ & $2.9 \times 10^{8}$ & $2.7 \times 10^{8}$ \\
61 & $4.9 \times 10^{7}$ & 18 \\
71 & $5.8 \times 10^{7}$ & 1 \\
7 & $7.2 \times 10^{7}$ & $1.8 \times 10^{3}$ \\
\hline
\end{tabular}

a Wild strain $\left(\mathrm{sp}^{+}\right)$.

\section{RESLLTS}

\section{Isolation of asporogenous mutant}

Two asporogenous mutants (No. 71 and 7 ) were obtained by ultraviolet irradiation and many asporogenous mutants were also obtained by acriflavine treatment, one of which was named strain No. 61. These mutants were concluded to be originated from the parent wild strain for the following reasons. (1) All mutants retain the leu- marker like the wild strain. (2) Morphological observation of these asporogenous mutants by electron microscopy at the magnification of 5,000 indicates that these mutants are similar to the wild strain. (3) These asporogenous mutants are able to form a spore per $10^{7}-10^{5}$ vegetative cells (Table 1 ) and these progeny spores also retain the leu- marker.

\section{Frequency of sporulation in asporogenous mutants and wild strain}

Frequencies of sporulation in asporogenous mutants and the wild strain were determined (Table 1). Though the wild strain had high sporulation frequency, asporogenous mutant strain No. 61 and No. 71 formed only one spore per $10^{6}-10^{7}$ vegetative cells and asporogenous mutant strain No. 7 formed only one spore per $10^{5}$ vegetative cells.

Sporulation frequencies of spores derived from these asporogenous mutants were also determined. The progeny spore of strain No. 61 had the same high frequency as that of the wild strain, but the progeny spores of strains No. 71 and No. 7 had the same low frequency as that of the parental asporogenous mutants.

\section{Growth of asporogenous mutants}

The wild strain (No. 111) and asporogenous mutants (No. 61, 71, and i) were grown in the Schaeffer medium of Spizizen's minimal medium (Figs. 1 and 2). The difference in growth rate between wild strain and asporogenous mutants was not detected at exponential growth phase when the strains were grown in the Schaeffer medium. However, decrease in optical density (660 $\mathrm{m} \mu$ ) caused by cell lysis was observed in asporogenous mutants at the sporulating stage. 


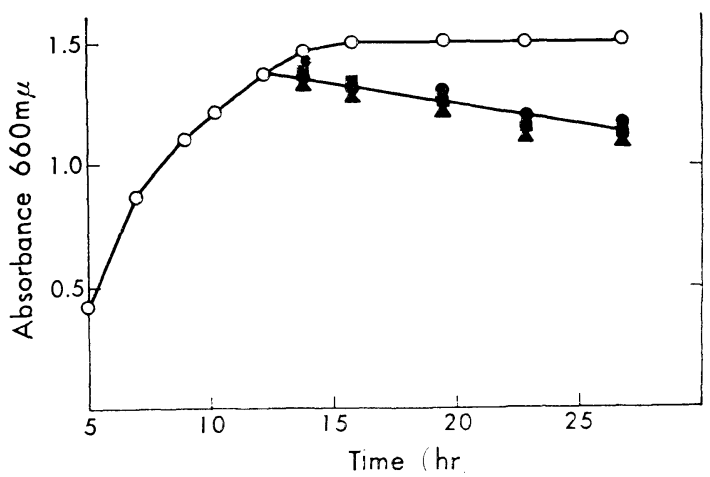

Fig. 1. Growth of mutant and wild strains on Schaeffer medium.

$$
\text { ○ } 111, \square 61, \Delta 71 \text {, }
$$

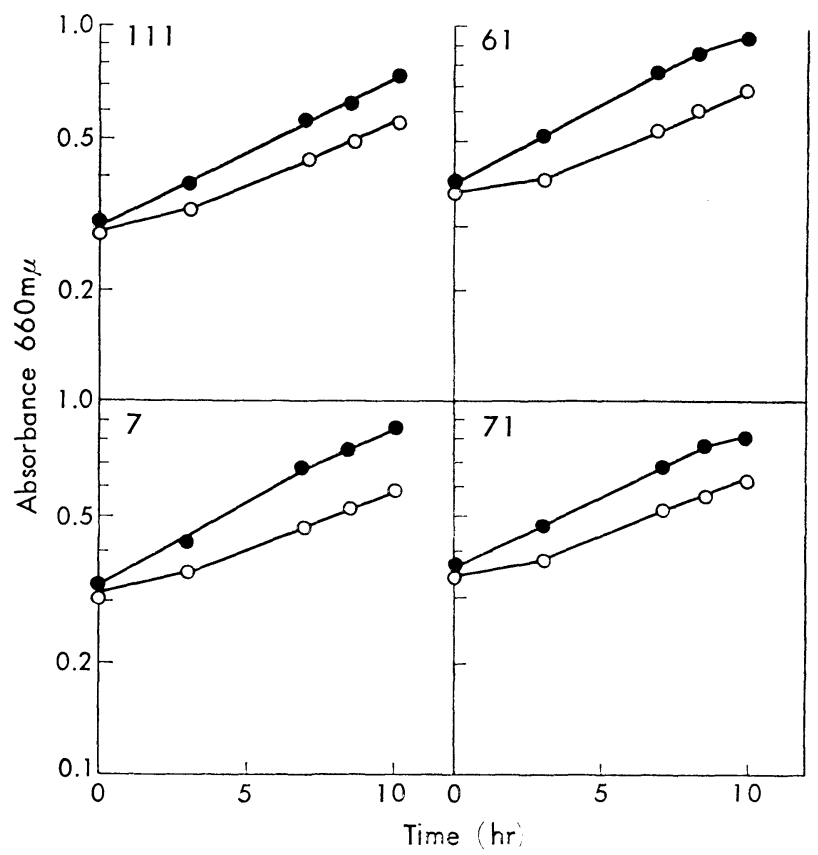

Fig. 2. Growth of mutants and wild strain on Spizizen minimal medium with glucose or glycerol as a carbon source.

- Glucose, O Glycerol 
Table 2. Dipicolinate content in wild strain and asporogenous mutants.

Total content of dipicolinate in the wild strain was about $8.1 \%$ in dry wt.

\begin{tabular}{c|c|c}
\hline 72 -hr cultivation & $\begin{array}{c}\text { Dipicolinate in cells } \\
(\mu \mathrm{g} / \mathrm{ml})\end{array}$ & $\begin{array}{c}\text { Dipicolinate in medium } \\
(\mu \mathrm{g} / \mathrm{ml})\end{array}$ \\
\hline $111 \mathrm{sp}^{+}$ & 75 & 22 \\
$61 \mathrm{sp}^{-}$ & $-a$ & - \\
$71 \mathrm{sp}^{-}$ & - & - \\
$7 \mathrm{sp}^{-}$ & - & - \\
\hline
\end{tabular}

a Not detected; $\mathrm{sp}^{+}$: wild strain, $\mathrm{sp}^{-}$: asporogenous mutants.

Exponential growth rates of wild strain and asporogenous mutants were not significantly different in minimal medium when glycerol or glucose was used as a carbon source. These results suggest that these mutants do not have any metabolic defects with reference to energy metabolism. Therefore, the asporogenecy in these mutants could not be caused by these metabolic defects.

Dipicolinate content and spore- specific enzymes in both wild and mutant strains

The amount of spore-specific component, dipicolinate, was examined in both the wild and mutant strains. As shown in Table 2, the wild strain could synthesize dipicolinate, while dipicolinate was not detected in these asporogenous mutants. These asporogenous mutants failed to form spores even in the presence of $97 \mu \mathrm{g} / \mathrm{ml}$ of dipicolinate in the Schaeffer medium. This result shows that asporogenecy in these mutants could not be caused by the defects in biosynthetic pathway of dipicolinate as reported by HALVORSON et al. (18).

Activities of several enzymes such as $\mathrm{NADH}_{2}$ oxidase and glucose dehydrogenase, which increase significantly during sporulation, were examined in both the wild and mutant strains $(13,14)$. Extracts were prepared and fractionated from the cells grown in the Schaeffer medium, and $\mathrm{NADH}_{2}$ oxidase and glucose dehydrogenase activities were measured. As shown in Table 3, these enzymes increased at the sporulating stage six or seven times as much as at the late stationary phase in the wild strain. However, the increase of these two enzymes was not seen at the sporulating stage in asporogenous mutants as shown in Table 4.

\section{Productions of exo-enzymes and antibiotics accompanied with sporulation}

The most striking characteristics at the early sporulating stage are the formation and release of antibiotics and of exo-enzymes such as proteases, ribonuclease, and amylase into the growth medium.

The formation of exo-enzymes and antibiotics in these asporogenous mutants was measured to know whether or not these asporogenous mutants were blocked at this early sporulating stage. These asporogenous mutants 
Table 3. Increase of enzyme activities during sporulation in wild strain.

Supernatant fraction $(15,000 \times g, 30 \mathrm{~min})$ of wild strain 111 was used as enzyme preparations.

\begin{tabular}{c|c|c} 
& $\begin{array}{c}\mathrm{NADH}_{2} \text { oxidase } \\
(\mu \text { moles mg min })\end{array}$ & $\begin{array}{c}\text { Glucose dehydrogenase } \\
(\mu \mathrm{moles} / \mathrm{mg} / \mathrm{min})\end{array}$ \\
\hline $\begin{array}{c}\text { O.D. } 1.10 \\
(9 \mathrm{hr}) \\
\begin{array}{c}\text { O.D. } 1.50 \\
(22 \mathrm{hr})\end{array}\end{array}$ & 0.018 & 0.008 \\
\hline
\end{tabular}

Table 4. Activities of $\mathrm{NADH}_{2}$ oxidase and glucose dehydrogenase in wild and asporogenous mutant strains.

Particulate fraction $(105,000 \times g, 3 \mathrm{hr})$ prepared from the cells of 22 -hr cultivation was used as enzyme preparations.

\begin{tabular}{c|c|c}
\hline $22 \mathrm{hr}$ & $\mathrm{NADH}_{2}$ oxidase & Glucose dehydrogenase \\
\hline 111 & 0.140 & 0.063 \\
61 & 0.007 & $-a$ \\
71 & 0.008 & - \\
7 & 0.011 & - \\
\hline
\end{tabular}

a Not detected.

Table 5. Exo-enzymes of wild and mutants strains of $B$. subtilis.

\begin{tabular}{c|c|c|c}
\hline & Protease & Amylase & Antibiotic $^{a}$ \\
\hline 111 & + & + & + \\
61 & + & + & + \\
71 & + & + & + \\
7 & + & + & + \\
\hline
\end{tabular}

a Antibiotic activity against Staph. aureus.

were able to produce amylase, protease, and antibiotics like the wild strain at the sporulating stage (Table 5).

\section{Breakdown and resynthesis of proteins during sporulation}

Previous experiments indicated that the excretion of exo-enzymes and antibiotics at the early sporulating stage occurred in these asporogenous mutants as in the wild strain, but these mutants were not able to synthesize spore-specific components such as dipicolinate, glucose dehydrogenase, and $\mathrm{NADH}_{2}$ oxidase which appear during sporulation.

It has been demonstrated from a phenomenon of endotrophic sporulation 


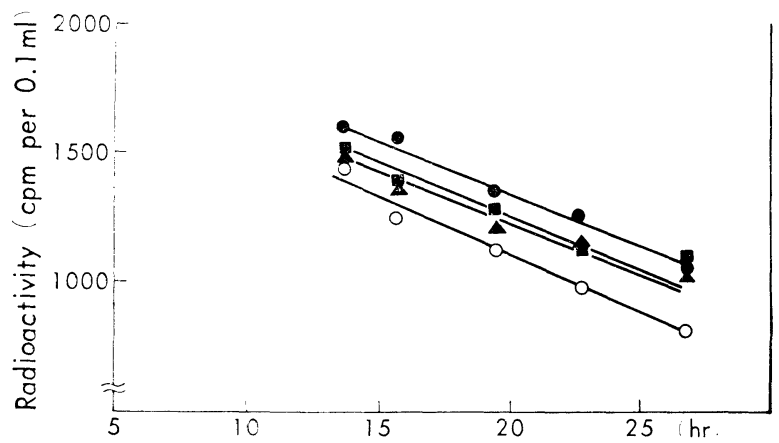

Fig. 3. Protein degradation during sporulation.

Cells were grown in $100 \mathrm{ml}$ of the Schaeffer medium with $100 \mu \mathrm{Ci}$ of ${ }^{3} \mathrm{H}$-L-leucine. After $13.5 \mathrm{hr}, 1.0 \mathrm{mmole}$ of L-leucine was added to the culture. C $111 \mathrm{Sp}^{+}, 61, \boldsymbol{\Delta} 71$, - 7 .

that amino acids needed for the synthesis of new spore-specific proteins can be induced by the breakdown of pre-existing cellular proteins (19). When sporulation was induced in cells, a large part of the vegetative cell proteins was degraded and the resynthesis of protein began so that total protein content remained nearly constant. On the other hand, there was no breakdown of vegetative cell proteins in the protease-less mutant (20). Each strain was grown in $100 \mathrm{ml}$ of the Schaeffer medium containing $100 \mu \mathrm{Ci}$ of ${ }^{3} \mathrm{H}$-L-leucine. After $13.5 \mathrm{hr}$, when sporulation was induced under these conditions, $1.0 \mathrm{mmole}$ of unlabeled L-leucine was added to the culture. Cell suspension $(0.1 \mathrm{ml})$ was sampled at appropriate time intervals, and the radioactivity of the acidprecipitable fraction was counted. Fig. 3 shows that there was a breakdown of vegetative cell proteins in both asporogenous mutants and the wild strain with the same degradation rate.

Next, we investigated whether the protein resynthesis occurred during sporulation stage in asporogenous mutants and the wild strain. Each strain was grown in $100 \mathrm{ml}$ of the Schaeffer medium. After $13.5 \mathrm{hr}, 50 \mu \mathrm{Ci}$ of ${ }^{3} \mathrm{H}-$ DL-phenylalanine was added to the culture. Cell suspension $(0.1 \mathrm{ml})$ was sampled at appropriate time intervals, and radioactivity of the acid-precipitable fraction was counted.

Protein synthesis during sporulation occurred in the wild strain, while little or no synthesis occurred in these asporogenous mutants as shown in Fig. 4. This might be the reason why these asporogenous mutants were not able to synthesize spore-specific components such as dipicolinate, glucose dehydrogenase, and $\mathrm{NADH}_{2}$ oxidase at the sporulating stage. 


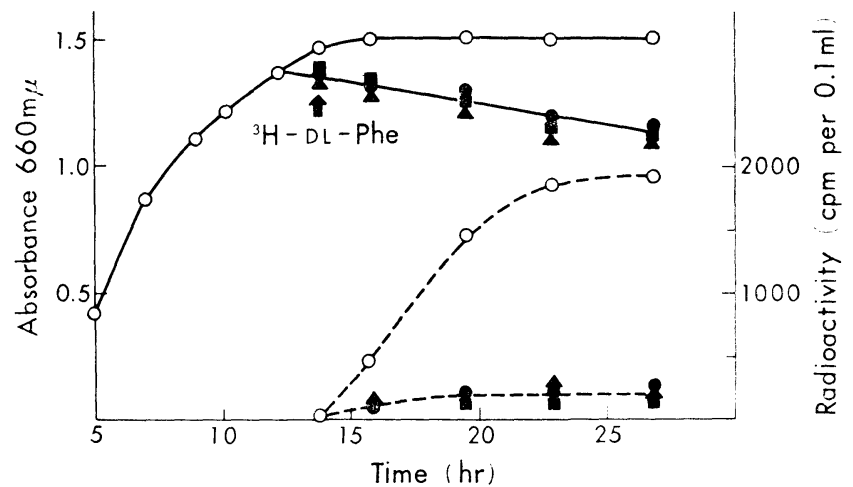

Fig. 4. Incorporation of ${ }^{3} \mathrm{H}-\mathrm{DL}$-phenylalanine into trichloroacetic acid-insoluble fraction.

${ }^{3} \mathrm{H}$-DL-Phenylalanine added after $13.5 \mathrm{hr}$ as indicated by an arrow.

- Absorbance at $660 \mathrm{~m} \mu$. ... Radioactivity.

$\bigcirc 111, \square 61, \Delta 71, \bullet 7$

\section{RNA synthesis during sporulation}

Our experiments showed that these asporogenous mutants lacked protein synthesis necessary for sporulation, and an examination was made to see whether these asporogenous mutants also lacked RNA synthesis during sporulation. Each strain was grown in $100 \mathrm{ml}$ of the Schaeffer medium. After $16 \mathrm{hr}$, when protein synthesis for sporulation occurred in the wild strain, $50 \mu \mathrm{Ci}$ of ${ }^{3} \mathrm{H}$-uracil was added to the culture. Cell suspension $(0.1 \mathrm{ml})$ was sampled at appropriate time intervals and radioactivity of the acid-precipitable fraction was counted. Although no protein synthesis was detected in asporogenous mutants after 16 -hr cultivation, RNA synthesis in these asporogenous mutants continued equally well as the wild strain, as shown in Fig. 5. RNase activity in asporogenous mutants seems to be the same as in the wild strain at the sporulating stage judging from the RNA content in the cells.

\section{Effect of addition of actinomycin on spore formation}

It has been reported that net RNA synthesis stops abruptly at stage 1 of sporulation, and total RNA per cell slowly decreases afterwards (21). However, some synthesis of RNA remains at the same period and, therefore, turnover of RNA is seen. Consequently, new kinds of messenger RNA (mRNA), not produced during vegetative growth, appear early in the sporulation stage $(22,23)$. Examination was made on the role of RNA synthesis seen after 16 -hr cultivation in the Schaeffer medium. Wild strain 111 was grown in $100 \mathrm{ml}$ of the Schaeffer medium, $5 \mathrm{ml}$ of cell suspension was sampled at various growth phases as indicated by arrows in Fig. 6, actinomycin was added to this cell suspension in a concentration of $10 \mu \mathrm{g} / \mathrm{ml}$, and the cells 


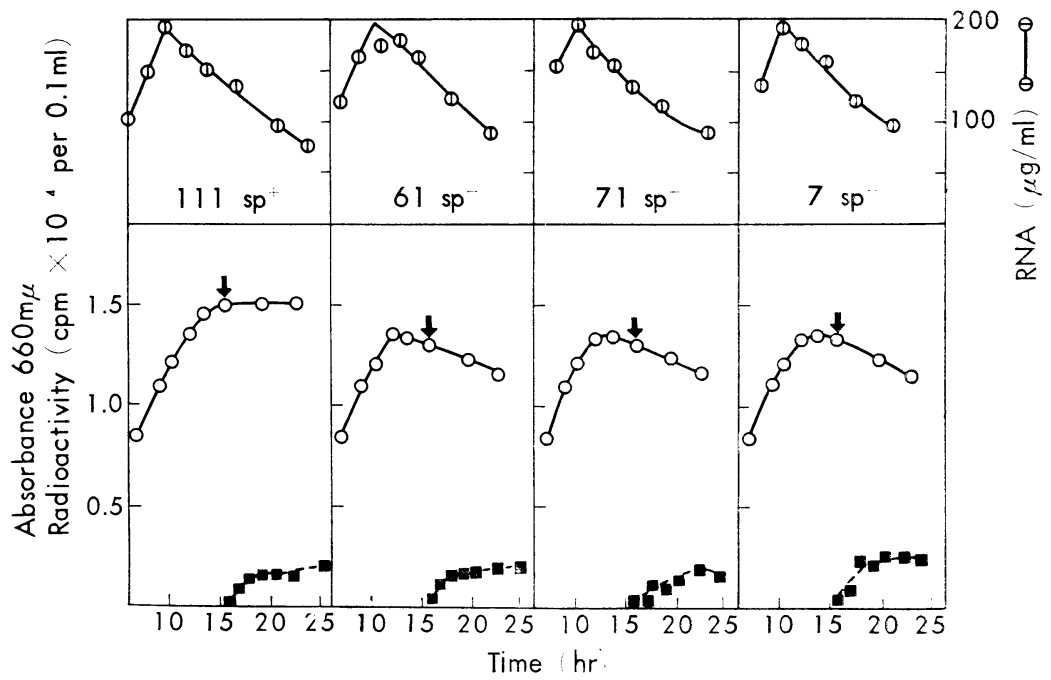

Fig. 5. Change in RNA content and incorporation of ${ }^{3} \mathrm{H}$-uracil into trichloroacetic acid-insoluble fraction.

${ }^{3} \mathrm{H}$-Uracil added after $16 \mathrm{hr}$ as indicated by an arrow.

$\bigcirc-\bigcirc$ Absorbance at $660 \mathrm{~m} \mu$.

ロ-- Radioactivity.

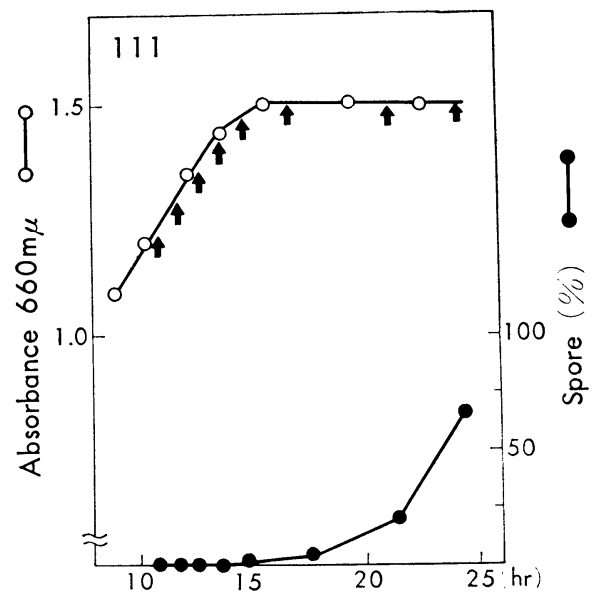

Fig. 6. Effect of the time of addition of actinomycin on spore formation.

Actinomycin added at the time indicated by arrows and cells were incubated for a total of $48 \mathrm{hr}$. Control values were $90-95 \%$ free spore. 
were incubated for $48 \mathrm{hr}$. The percentage of spores in the culture was determined by plating the culture on the Schaeffer agar medium after heating at $80^{\circ}$ for $30 \mathrm{~min}$. Actinomycin $(10 \mu \mathrm{g} / \mathrm{ml})$ inhibited RNA synthesis of $B$. subtilis 111. Fig. 6 indicated that RNA synthesis which was seen around 15 $-16 \mathrm{hr}$ after the inoculation seemed to be essential for sporulation in the wild strain.

\section{DISCUSSION}

The deletion region in these asporogenous mutants seemed to be of a considerable size, as detected by ${ }^{3} \mathrm{H}$-DL-phenylalanine incorporation experiment during sporulation. In spite of a possibility of large deletion, additional phenotypes were not detected in these mutants, except for the $\mathrm{sp}^{-}$character compared with the wild strain from which the asporogenous mutants were derived.

Recently, IKEDA et al. (24) reported that many asporogenous mutants of $B$. subtilis were obtained by high temperature $\left(48^{\circ}\right)$ cultivation. We have also obtained several other asporogenous mutants which were blocked at the early sporulation stage, such as strain Nos. 61,71 , and 7 , by various methods including high temperature treatment. Therefore, it was assumed that the asporogenous mutant (strain No. 61) obtained by acriflavine treatment might have been produced by high temperature $\left(45^{\circ}\right)$ cultivation rather than by acriflavine treatment.

No protein synthesis seemed to occur at the sporulating stage in these asporogenous mutants while RNA synthesis seemed to occur normally (Figs. 3 and 4 ), therefore, it is possible to consider that these mutants have defects at the translation level of protein synthesis for sporulation. However, the possibility that these mutants could not synthesize m-RNA for sporulation cannot be neglected. We have no data yet to clarify these points and the site of defects in spore-specific protein synthesis in asporogenous mutants is still unknown. Preliminary experiment showed that sedimentation patterns of the ribosomes in both the wild strain and the mutants were identical at the sporulating stage.

We thank Dr. H. Saito for the donation of the organisms and Prof. H. Yonehara for actinomycin.

\section{REFERENCES}

1) P. Schaeffer, H. Ionesco and F. JAcob, Compt. Rend., 249, 577 (1959).

2) P. Schaeffer and H. Ionesco, Compt. Rend., 251, 3125 (1960).

3) J. Spizizen, In Spores III, ed. bý L.L. Cam?Bell and H.O. Halvorson, American Society for Microbiology, Ann Arbor, Mich. (1965), p. 125.

4) I. Takahashi, Biochem. Biophys. Res. Commun., 5, 17 (1961). 
5) I. Takahashi, J. Bacteriol., 89, 1065 (1965).

6) I. Takahashi, In Spores III, ed. by L.L. CAmpbell and H.O. Halvorson, American Society for Microbiology, Ann Arbor, Mich. (1965), p. 138.

7) J.A. Hoch and J. SpizizeN, In Spores IV, ed. by L.L. Campbell, American Society for Microbiology, Bethesda, Maryland (1969), p. 112.

8) C. Anagnostropoulos and J. Spizizen, J. Bacteriol., 81, 741 (1961).

9) P. Schaeffer, J. Millet and J. Aubert, Proc. Nat. Acad. Sci. U.S., 54, 704 (1965).

10) M. Rogolsky and R.A. Slepecky, Biochem. Biophys. Res. Commun., 16, 204 (1964).

11) F.W. Janssen, A.J. Lund and L.E. Anderson, Science, 127, 26 (1958).

12) O.H. Lowry, N.J. Rosebrough, A.L. Farr and R.J. Randall, J. Biol. Chem., 193, 265 (1951).

13) J. Szulmajster and P. Schaeffer, Compt. Rend., 252, 220 (1961).

14) J.A. BACH and H.L. SAdOFF, J. Bacteriol., 83, 699 (1962).

15) H.L. SAdoff, J.A. BACH and J.W. Kools, In Spores III, ed. by L.L. CAmpbelL and H.O. Halvorson, American Society for Microbiology, Ann Arbor, Mich. (1965), p. 97.

16) W.C. SchneIder, J. Biol. Chem., 161, 293 (1945).

17) W.Z. Mejbaum, Physiol. Chem., 258, 117 (1939).

18) H.O. Halvorson and A. Swanson, In Spores IV, ed. by L.L. Campbell, American Society for Microbiology, Bethesda, Maryland (1969), p. 121.

19) J.W. Foster and J.J. Perry, J. Bacteriol., 67, 295 (1954).

20) J. Mandelstam and W.M. Waites, Biochem. J., 109, 793 (1968).

21) C.R. Spotts and J. Szulmajster, Biochim. Biophys. Acta, 61, 635 (1962).

22) A.I. ARonson, J. Mol. Biol., 11, 576 (1965).

23) A.I. Aronson and M.R. Del-Valle, Biochim. Biophys. Acta, 87, 267 (1964).

24) Y. Ishir, H. SAito and Y. IKedA, Abstracts of the Ann. Meet. of the Agr. Chem. Soc. Japan, p. 274 (1969), abstract in Japanese. 